\title{
DiLA at 3o: A Personal Reflection
}

\author{
Kevin Y.L.Tan*
}

I seem to be getting a lot of requests for 'reflection' pieces these days. I'm quite sure it's more a sign of my advancing years than because I am a legal historian. This 'reflection' will be partly historical and partly personal. While the Foundation for the Development of International Law in Asia (DILA) was established in December 1989, I have only been directly involved in its activities since April 1997. I have previously briefly written about the founding of D ILA in the pages of this Yearbook. ${ }^{1}$ While I will try my best to avoid repetition, some material will invariably overlap with that previous reflection. I try to be as accurate as possible in my documentation of events, even if many of the views and perspectives expressed are personal.

\section{$2 \quad$ Foundational Moments}

\subsection{Towards a Pan-Asian International Law Organisation ${ }^{2}$}

The birth of any organisation begins with an ideal and an inspiration. The case is no different with societies of international law. While international law has been practised since the $15^{\text {th }}$ century, communities of international law scholars did not organise themselves into societies to promote the study of international law till the latter part of the 19th century. It also took the international community a long time to recognise the importance of international law in the law student's curriculum. We often forget that the first chair in international law at the University of Oxford - the Chichele Chair in International Law and Diplomacy - was only established in 1859, even though the university itself dates from the 12th century. The same can be said of the University of

* Adjunct Professor, Faculty of Law, National University of Singapore, and Visiting Professor, S Rajaratnam School of International Studies, Nanyang Technological University; former Chairman of DILA and Editor-in-Chief of the Asian Yearbook of International Law.

1 Kevin YL Tan, 'The Asian Yearbook of International Law 1995-2015: A Historical and Personal Reflection' (2014) 20 Asian Yearbook of International Law 1-11.

2 Part of this segment appeared as Kevin YL Tan, 'Speech delivered at the Inauguration of the Asian Society of International Law, 78 April 2007 at the Faculty of Law, National University of Singapore (2007) 13 Asian Yearbook of International Law 21-26. 
Cambridge, where the Whewell Professorship in International Law was established in 1869 .

The first international law society was established through the inspired energies of a Belgian scholar and government official, Gustav Rolin-Jaequemyns, founding editor of the first scholarly international law review, the Revue de Droit International (1869). In September 1871, he received a letter from one of the Revue's contributors, the German émigré Professor Francis Lieber of Columbia Law School, proposing an international law society. ${ }^{3}$ Lieber had been pushing this idea privately for the past decade. In 1873, a group of 10 eminent scholars and Rolin-Jaequemyns met in Ghent 1873 and established what is now known as the Institut de Droit Internationale. In Asia, the first society of international law was the Japanese Society of International Law, founded in 1897. Republican China established the Chinese (Taiwan) Society of International Law in 1913, and the People's Republic of China established the Chinese Society of International Law in 1980. In between, the Indian Society of International Law was established in 1959. In 1902, a group of Japanese scholars, led by Professor Sakuye Takahashi, established the Review of International Law (Revue de Droit Internationale), the first international law publication of its kind in Asia.

However, there was no organisation to facilitate dialogue and discourse between students and scholars on a pan-Asian basis. Indeed, the first such regional organisation was the African Association of International Law, established in 1986. Against this backdrop, DILA was founded on 21 December 1989 by three Asian émigré international lawyers - Ko Swan Sik, JJG Syatauw and MCW Pinto - then living in the Netherlands.

\subsection{The Three Founders: Ko Swan Sik, JJG Syatauw \& MCW Pinto}

Ko was born on 4 January 1931 in Magelang in Central Java, Indonesia. His father, Ko Tjay Sing and granduncle, Ko Kwat Tiong, were both distinguished legal scholars and academics. ${ }^{4}$ Ko graduated from the Faculty of Law of the University of Indonesia in 1953, after which he proceeded to Leiden University, where he obtained a PhD (cum laude) in 1957. During his studies in Leiden, Ko spent a year at the University of Mainz and attended the Hague Academy of International Law's summer course in 1954. He returned to Indonesia after his studies and practised as an attorney in Semarang between 1957 and 1963 and

3 Irwin Abrams, 'The Emergence of International Law Societies' (1957) 19(3) The Review of Politics $361-380,367-368$.

4 For this brief biographical account, I relied on Leo Suryadinata, Prominent Indonesian Chinese: Biographical Sketches, 4 ed (Singapore: ISEAS Yusof Ishak Institute, 2015) 102-105. 
then in Jakarta from 1963 to 1965 . Between 1959 and 1965 , he was concurrently Senior Lecturer of Public International Law at the University of Indonesia. In February 1965, Ko left for the Netherlands where he joined the newly-created TMC Asser Institute of International Law at The Hague where, among other things, he founded the Netherlands Yearbook of International Law in 1970. In 1988, he moved to Rotterdam, where he became Professor of International Law at Erasmus University, taught till 1996 when he retired and was made professor emeritus.

Ko's close collaborators in the DILA enterprise were Jacob Johannes Gustaaf ('Joop') Syatauw, another Indonesian international law scholar, and Moragodage Christopher ('Chris') Walter Pinto, a diplomat and scholar. Pinto just slightly younger than Ko. He was born on 17 November 1931 in Colombo, Sri Lanka (then Ceylon), to Moragodage Walter Leopold Pinto and Judith Beatrice Blazé. He studied at the University of Ceylon at Peradeniya, where he graduated with an LLB degree. He then attended the Sri Lanka Law College where he qualified as an Attorney and after that studied at Magdalene College, Cambridge University, where he obtained his master's degree (then known as an 'LLB' rather than as an 'LLM') at Cambridge and a Diploma in International Law. He was called to the Bar at the Inner Temple in 1958. Pinto worked as a legal officer in the International Atomic Energy Agency in Vienna between 1960 and 1963, and then in the Legal Department of the World Bank from 1963 to 1967. He then returned to Sri Lanka to become Legal Advisor and Head of the Legal and Treaties Division of the Ministry of Foreign Affairs, a post he held till 1979. In 1976, he became Sri Lanka's Ambassador to Germany and Austria. Pinto represented Sri Lanka at the UN Conference on the Law of the Sea between 1980 and 1981 and was, from 1982, Secretary-General of the United States-Iran Claims Tribunal till his retirement in 2011. During this last phase of Pinto's career, he came into contact and worked with Ko in the founding of DILA.

The late Joop Syatauw 5 was born on 9 December 1923 in an army camp in Bandung, where his father was stationed as a Non-Commissioned Officer of the Royal Netherlands Indies Army (KNIL). His family came from the island of Ambon in the Moluccas. Syatauw's secondary education was interrupted by the Japanese Occupation (1942-1945), and he worked in the Department of Mining in Bandung during the War. In 1949, he obtained a scholarship to study at Leiden, where he graduated with an LLM and then proceeded to Yale Law

5 Most of the following information about Professor Syatauw was kindly shared by Professor Ko Swan Sik in two emails to me, dated 20 Mar 2015 and 8 Apr 2015. 
School. He obtained his JSD in 1960 for his thesis, Some Newly Established Asian States and the Development of International Law. ${ }^{6}$

After completing his doctorate, Syatauw spent some time doing additional research at the London School of Economics and Social Science. Upon his return to the Netherlands, he became assistant to Haro Fredrik Van Panhuys, Professor of International Law at the University of Leiden. At Van Panhuys' prompting, Syatauw joined the Institute of Social Studies (ISs) in The Hague as 'Lector' - a junior professor, and the Iss's highest academic position in the early 1960s - in the Department of International Law and Relations and remained there till his retirement as Professor in 1988. When Ko was still in Indonesia, he heard about one JJ Syatauw sometime in 1961 when 'rumours began to circulate about an Indonesian who had obtained his JSD at Yale on a dissertation on newly-established Asian states.' However, it was not till 1965, when Ko relocated to The Hague, that he first met Syatauw.

\subsection{The Ideas and the Team Come Together}

Even if it is often said that Ko, Syatauw and Pinto collectively founded DILA, there is little doubt that Ko was its prime mover and organiser. Ko recalled the state of scholarship in the field of international law in those early days:

At occasional meetings in the 1980s, some Asian jurists living in Western Europe and working in the field of international law and their colleagues from Asia developed the idea of launching activities to enhance contacts among a wider circle of Asian international law jurists; and initiating joint projects in the field of international law related to Asia. The idea was not new, and neither were the attempts to materialise it. In previous decades, various projects involving senior Asian scholars in the field had been undertaken, but none of these efforts had really been successful. Some were simply stranded soon after their inception. However, these failed attempts contributed strongly to the desire to renew and redouble these efforts. ${ }^{7}$

Ko's motivations in initiating 'projects focused on Asia and Asians' were primarily cultural and political. He was driven by the sense of solidarity that 'persists among [Asians] ... as a result of the numerous mutual cultural and

6 JJG Syatauw, Some Newly Established Asian States and the Development of International Law (The Hague: Martinus Nijhoff, 1961).

7 Ko Swan Sik, 'DILA: A Brief History' (unpublished manuscript on file with author) [hereinafter 'Ko']. 
religious contacts and interconnections that have emerged and developed in the course of centuries, and as a consequence of a common experience of European and other Western domination and dominance, both in the form of downright colonisation and semi-colonisation as well as otherwise.8 Ko was also concerned that interactions between legal scholars in Asia were few and far between and that their 'mutual familiarity and ... knowledge and appreciation of the law and its development within and between the countries of the region' was grossly lacking. Indeed, it seemed absurd that many Asian jurists turned 'instinctively, and exclusively, to Western models and strategies based on society structures and national interests which are different from their own, and prefer to ignore those tried out by neighbouring and other regional, similarly structured, countries. ${ }^{9}$ In summary, Ko stated:

The ambitions contained in the above ideas have several inseparable features. First, there is the issue of re-orientation, including the reassessment of our approach to the outside world, particularly the West, and putting our view of the latter definitively in a more regional perspective. This should in no way imply a tendency to isolate ourselves from the treasure trove of Western genius and legal scholarship from which innumerable lessons could, and should, still be learnt. But it does mean the need for a (more) critical judgement, together with the determination to strengthen our efforts, test and prove our ability to materialise and carry out ourselves, whatever needs to be done in our professional field without relying on and waiting for others. Another feature is the acknowledgement that the views and practices of the countries of the region in the field of law, and more particularly international law, are underexposed in the existing literature and publications and should thus be better and more comprehensively presented to the world, both inside and outside the region. A third feature has a didactic element and consists of the promotion of the study of and research and publication in the field of international law, both in general as well as in specifically Asian perspective, by Asian students and scholars. ${ }^{10}$

The impetus for establishing DILA and the Asian Yearbook of International Law came in 1983 when Ko was nominated to participate in organising an international symposium to commemorate the 4ooth birth anniversary of Hugo

$8 \quad I d$.

$9 \quad I d$.

10 Id. 
Grotius. As part of the effort to emphasise the international character of this meeting, Ko selected and invited several speakers from outside Europe, especially from Asia. As a result of this gathering of Asian scholars, it was decided that a 'concrete start' be made to mobilise Asian scholarship by putting together and publishing a book 'on a topic easily capable of being presented from the perspective of the different views and practices of the various countries of the region.. ${ }^{11}$ It was further decided that the topic for the book had be 'basic and yet of the greatest importance in the municipal as well as the international practice of states.' ${ }^{12}$ To this end, Ko persuaded the Martinus Nijhoff - a Leiden-based academic press that had been established in Belgium in 1853 - to start a new series entitled International Law in Asian Perspective. By the 197os, Nijhoff had a formidable reputation as an independent publisher of international law books. ${ }^{13}$ Ko credits Professors Chang Hyo-Sang and Chiu Hungdah (then from Hanyang University and the University of Maryland, respectively) for proposing the topic for the first volume in a projected book series. This volume, entitled Nationality and International Law in Asian Perspective, ${ }^{14}$ comprised ten chapters by different Asian contributors. ${ }^{15}$ Ko edited the volume and published it in 199o. Unfortunately, the series was difficult to sustain and failed to take off. Only one other volume was published under its auspices in $1995 \cdot{ }^{16}$ Nevertheless, the collective efforts involved in this book led to the idea of publishing a Yearbook. Ko explained:

The experience of editing and publishing this volume taught us that while a collective monographic effort as the one mentioned above had proved to be undoubtedly worthwhile, the limited manpower available at our disposal to direct such projects lead to the conclusion that preference, or rather priority, should be accorded to the publication of a periodical publication which would be able to cover a broader scope and, hopefully, a broader public. A quarterly publication was considered ideal, but the

\footnotetext{
$11 \quad I d$.

12 Id.

13 Martinus Nijhoff was acquired by Wolter Kluwer in the 1970s and subsequently by Brill Publishers.

14 Ko Swan Sik (ed), Nationality and International Law in Asian Perspective (Dordrecht: Martinus Nijhoff, 1990).

15 The Asian contributors to the volume were: Rafiqul Islam, Chiu Hungdah, SK Agrawala, M Koteswara Rao, Ko Swan Sik, Teuku Mohammad Rahdie, Hosokawa Kiyoshi, Chang Hyo Sang, Visu Sinnadurai, Irene R Cortes, Raphael Perpetuo M Lotilla, M Sornarajah and Sompong Surcharitkul.

16 P Chandrasekhara Rao, The Indian Constitution and International Law (Dordrecht: Martinus Nijhoff, 1995).
} 
available manpower and the uncertain response from colleagues in the region made it an unfeasible proposition. Hence the alternative resolution to start a Yearbook. ${ }^{17}$

Having arrived at the preferred mode of academic engagement, research and dissemination, it was now necessary to establish a corporate vehicle to effect this plan. Ko was particularly concerned that the founders/editors of the new Yearbook should not be personally liable for the financial success of the publication. He recalled:

The possibility of financial consequences of the publication project and the wish of preventing individual persons from being burdened with such responsibility gave rise to the decision of founding a separate legal entity under whose auspices the Yearbook would be published. The entity that finally came about and that was DILA happens to be moulded in the formal structure of a 'foundation' under Dutch law for the simple reason that the founders, MCW Pinto (Sri Lanka), Ko Swan Sik (Indonesia) and JJG Syatauw (Indonesia) had their residence in the Netherlands. The official founding of DILA took place on December 21, 1989, by deed of a notary public in The Hague. ${ }^{18}$

Nonetheless, Ko was quick to point out that while the founding of DILA was 'primarily intended to meet the contingency of financial responsibility in connection with the publication of the Yearbook', it was not 'an organisation for the exclusive purpose of publishing the Yearbook'. Instead, it embodied

... a rather broad program of academic activities in the field of international law in Asia or relating to Asia, thereby aiming at promoting contacts among Asian jurists, enhancing their endeavours in the field of research and education, improving their information of whatever developments in the field of research and literature in the field concerned, and promoting the recording and dissemination of relevant Asian materials. ${ }^{19}$

When Ko began conceptualising the Asian Yearbook in 199o, he turned to Pinto and to Syatauw for support. He recalled:

\footnotetext{
17 Ko ( $\left.\mathrm{n}_{5}\right)$.

18 'A Dialogue with Judicial Wisdom: Professor Ko Swan Sik' (2010) 3(2) Journal of East Asia and International Law 451, at 455 .

19 Id. at $455^{-4} 46$.
} 
When I decided to start the DILA project, I decided that what I needed most was a number of people around me by way of touchstone who were able to share the essentials of my ideas and who would be approachable at any time to be consulted on the elaboration and realisation of any plans. It was obvious that, next to Pinto, Joop was most qualified to be invited as a member of the team. ${ }^{20}$

Ko then broached the idea of publishing the Yearbook with Martinus Nijhoff, who expressed an immediate interest in the enterprise and agreed to assume the financial risks of the publication 'provided there was a favourable response' to the experimental first volume. ${ }^{21}$ That meant that the founders still needed to find money to produce the first volume of the Yearbook. They approached well-established American, European and even Japanese charitable foundations but failed to secure financial support. They then turned to the Dutch Ministry of Development Cooperation, who agreed to subsidise the production costs of the first volume and made a further grant for the purchase of 200 copies 'from the publishers for distribution among Asian government and academic institutions by way of introduction.'22 The entire subvention from the Dutch Ministry went to the publishers. This generous grant was followed up some years by an equally generous donation from the Swedish International Development Authority for the continued publication of the Yearbook. ${ }^{23}$

As noted above, DILA's initiators had decided to legalise DILA's existence as a charitable foundation or stichting under Dutch law because it was too much work to establish an 'association'. The initiators decided to structure the organisation as a charitable foundation. DILA was thus established by notarial deed at The Hague on 21 December 1989 with the aims to promote:

a. the study and analysis of topics and issues in the field of international law, in particular from an Asian perspective;

b. the study of, and the dissemination of knowledge of, international law in Asia;

c. contacts and cooperation between persons and institutions actively dealing with questions of international law relating to Asia.

$\begin{array}{ll}20 & \text { Ko Swan Sik to Kevin Tan, 20 Mar } 2015 . \\ 21 & \text { Ko }\left(\mathrm{n}_{5}\right) . \\ 22 & \text { Id. } \\ 23 & \text { Id. }\end{array}$ 


\section{Beyond the Founding}

\subsection{The Yearbook}

In 1991, the first issue of the Asian Yearbook of International Law was published. The international law fraternity warmly welcomed it, and Martinus Nijhoff was sufficiently encouraged to assume full ownership of the Yearbook by taking care of its entire publication and distribution costs, at least insofar as the second issue was concerned. DILA's founders constituted themselves as General Editors of the Yearbook with principal responsibility for its editing and publication. The rest of the Editorial Board comprised some of the most distinguished Asian international law scholars at the time: Chang Hyo Sang (South Korea), Rahmatullah Khan (India), Onuma Yasuaki (Japan), M Sornarajah (Sri Lanka), and Sompong Sucharitkul (Thailand). Despite the inclusion of many distinguished scholars as part of the Yearbook's editorial boards through the years, the three founding General Editors remained primarily responsible for its content, quality, and publication right up till 2009.

The founding General Editors explained what they planned to do in the first volume of the Yearbook:

It is the aim of the General Editors to include in each volume of the Yearbook, in addition to scholarly essays of an analytical, descriptive or speculative nature, materials that are evidence of the practice of States in the region. To that end the General Editors are currently engaged in trying to establish a network of correspondents in Asian countries, who would keep them currently informed of significant developments, and provide them with the associated documentation on a regular basis. The problem of securing and maintaining the collaboration of scholars, all of whom are already fully engaged in routine pursuits of their own, is compounded by a variety of difficulties, including variations in the efficiency of communications and the fact that no funds are available to compensate collaborators for their efforts, or even for expenses connected with providing information. Also to be included in the Yearbook are a chronicle of events relating to the region and of relevance from an international law perspective, notes on selected activities of regional and international organisations, and a survey of selected works in the field of international law. ${ }^{24}$ 
As I have written previously on the developments relating to the Yearbook, I will not repeat that here but will instead focus on DiLA's development as an organisation.

\subsection{Finances \& Benefactors}

From its inception, DILA's founders worried about the financial viability of the Yearbook. They secured funds for the publication of its first issue from the Dutch Ministry of Development Cooperation, and Martinus Nijhoff underwrote the costs of Volume 2 of the Yearbook. However, Nijhoff needed them to raise further for funding Volume 3. DILA's founders then approached the Swedish International Development Authority who donated US\$45, ooo to defray the costs of producing the third volume. Thereafter, funds were still required each year to help pay for preparing the layout of the Yearbook, copyediting, and the bulk purchase of the Yearbook for distribution to contributors and institutions.

This financial lurching from year to year was unsustainable, and it was the late Professor Onuma Yasuaki (1946-2018) who took the initiative to do something about it. Onuma was, at the time, a member of the Editorial Board and Professor of International Law at the University of Tokyo. He decided to approach his friend and neighbour, Sata Yasuhiko ('Mike' Sata), a wealthy industrialist, for support. Sata - who ran the Tokibo Group, one of Japan's leading manufacturers of medical devices - was a humanitarian philanthropist with a deep interest in international affairs. Sata agreed to contribute to the cause of DILA and the Yearbook as well as to Onuma's international law projects generally. Sata made three donations to DILA through the Japan Foundation between 1997 and 1999. At the same time, Sata also made a ¥2m donation towards supporting Onuma's projects through the University of Tokyo. This second donation was to be the subject of an unfortunate misunderstanding between DILA Governing Board members in 2005, as I will later recount. Over the years, Mike Sata remained the strongest and staunchest supporter of DILA, making regular donations of ¥1m a year to sustain the Yearbook and also to start and fund the Sata Prize (renamed the DILA Prize in 2008) for the best article by a young scholar (below the age of 35 years) in the Yearbook. In later years, DILA continued to raise funds and receive support from various other foundations and organisations, but these will be discussed in the appropriate segment of the narrative. 


\section{Rejuvenation and Renewal}

\subsection{Manila 1997}

In the first few years after its inauguration, the General Editors of the Yearbook found their hands full with securing good articles, compiling the Chronicle section, and establishing contacts and correspondents in various Asian countries to assist with the State Practice section. Besides editing the journal, the founders were also busy networking with Asian international law scholars and other international law scholars with an interest in Asia. Ko was particularly relentless in contacting, meeting, and securing the support of as many scholars as he could. This enthusiasm, coupled with the high quality achieved by the Yearbook in its first few volumes, helped boost the Yearbook's reputation further. But this was not enough. DILA's other objectives were not fulfilled, and the founders thought it would be good to organise a significant international law conference for Asian scholars. It was to this end that another round of fund-raising began. However, by the end of 1994, Ko had succeeded in raising only US\$20,00o, which was insufficient for a major conference. These moneys were subsequently used to hold a meeting of the DILA Governing Board in Manila in April 1997. Strictly speaking, the meeting was held in Quezon City, even if everyone refers to it as the 'Manila meeting'.

The convening of the 1997 meeting led to my association with DILA and the Yearbook. I was not supposed to be at that meeting but was asked by my senior colleague, Professor Tommy Koh (then a member of DilA's Advisory Board), to attend on his behalf. Ko's invitation to Tommy suggested that if he could not attend the meeting personally, he should designate another person to act as his 'personal representative' and that this representative 'should, apart from being familiar with international law, be familiar also with the state of affairs regarding the practice, teaching and research of international law' in Singapore. ${ }^{25}$ Tommy offered Ko two possible 'representatives' - Yeo Bock Chuan, then Head of the International Law Division at the Ministry of Defence, and me. It is most likely that Ko invited me because I was the academic among the two. I protested to Tommy, arguing that I felt inadequate attending this meeting. While I had studied many international law subjects at the undergraduate and graduate levels, I never considered myself an international law scholar or teacher. Indeed, I never taught the subject since joining the Faculty of Law at the National University of Singapore (NUS) in 1986. Indeed, my speciality had been and continues to be constitutional and administrative law. The only possible reason warranting my attending this meeting was that, at the time, I was

25 Ko Swan Sik to Tommy Koh, 12 Feb 1997 (on file with author). 
the Honorary Secretary of the recently-established Society of International Law, Singapore. ${ }^{26}$ Tommy, ever persuasive, assured me that all would be well and that all I had to do was attend the meeting, take notes and report back to him. I reluctantly agreed, and on 18 February 1997, received a personal invitation from Ko. ${ }^{27}$

In his invitation, Ko explained that the meeting was to 'discuss various issues of study, research and dissemination of international law relating to Asia, take stock of the achievements of DILA so far and set up a strategy for future activities and projects in accordance with the purposes of the Foundation'. ${ }^{28}$ Unlike what Tommy imagined, the preparation for the Manila meeting was substantial. Ko prepared a detailed set of discussion papers for our digestion before arrival, and it was in reading through them that I first understood what DILA was all about. The Manila meeting was hosted by the Institute of International Legal Studies (ILS) at the University of the Philippines Law Centre. It was held from 4 to 5 April 1997 at the Imperial Palace Suites in Quezon City. Maria Lourdes Sereno, ${ }^{29}$ the Director of the ILS, was our host and did a superb job organising the meeting. One thing that struck me at the meeting was the relative seniority of the scholars present. I was the youngest there. ${ }^{30}$

The meetings were intense and among the critical issues discussed were (a) the structure and organisation of DILA and rejuvenation of its Governing Board; (b) relocating DILA's headquarters to Asia; (c) the Yearbook; and (d) further activities and actions for DILA. Many ideas were canvassed and ideas proposed. As I later discovered, these same ideas and proposals tended

26 The Society for International Law, Singapore was established in 1995 to provide a platform for scholars, students and practitioners of international law in Singapore to meet, dialogue and to promote the study and research of international law. At its founding, Tommy Koh was President. My colleague at NUs, Robert C Beckman was Executive Director while I was Honorary Secretary. I served in this capacity till 1998 when I took over as Executive Director. I stepped down from the Executive Committee in 2003.

27 Ko Swan Sik to Kevin Tan, 18 Feb 1997 (on file with author).

28 Id.

29 Sereno was to become, in 2012, the first woman Chief Justice in the Philippines (and in Southeast Asia for that matter). Unfortunately, she was removed after an 8-6 decision of the Supreme Court in a controversial quo warranto petition.

30 Others at the meeting were: DILA founders Ko Swan Sik and Chris Pinto; Chung Il-Yung (South Korea) representing Judge Park Choon Ho, Florentino Feliciano (Philippines); James Li Zhaojie (China) representing Prof Wang Tieya; Raphael M Lotilla and Dean Merlin Magallona (Philippines); VS Mani (India) representing Prof Rahamtullah Khan; Jamal Seifi; Sidek Suraputra (Indonesia); Sompong Sucharitkul (Thailand); Surya Subedi (Nepal); Nakatani Kazuhiro (Japan); and of course our host, Maria Sereno (Philippines). Absent with apologies were: JJ Syatauw (Indonesia); Jamshed A Hamid (Pakistan); Ronald St John MacDonald (Canada) and Judge Soji Yamanoto (Japan). 
to be repeatedly canvassed at DILA's subsequent meetings. My main contribution to the meeting was my suggestion that a web page be created for DILA as an alternative to a proposed newsletter. I was thus designated to work on this project with James Li and Maria Sereno. Another major project presented at the meeting was the preparation of an Asian Manual of International Law along the lines of the highly successful two-volume by Professor Georg Schwarzenberger. Professors Ko, Subedi and Seifi were tasked with executing this major project under the chairmanship of Prof Rahmatullah Khan. Finally, it was decided that a major international law conference be organised as soon as possible. This last initiative was bolstered by the announcement by Park Il-Yung that the Paeksang Foundation (which he then chaired) would give DILA a generous donation which would be used towards organising this conference.

\subsection{The Hague Meeting of 2000}

As with so many of these things, the DILA group's enthusiasm displayed in Manila faded quickly when we all returned to our respective jobs. It was no different on my end. I tried to get some student volunteers to help set up a website, but little was done save for the registration of our domain name 'asianinternationallaw.org' - as determined and instructed by the Governing Board at the 1997 meeting. In fact, it was not till 1999 that a rudimentary website was established with the help of a professional website designer. There was also little progress on the Asian Manual project, and talk of our having a big conference in Korea all but petered out. Only the Yearbook grew from strength to strength. Concerned that the transition and rejuvenation were not going according to schedule, Ko convened another meeting in January 2000 in The Hague.

Unlike the Manila meeting, this meeting comprised a small group of Governing Board members, which Ko called The Core Group. Other than the three DILA founders, the Core Group members were: Jamal Seifi, Surya Subedi, James Li and Nakatani Kazuhiro (who were all present at the Manila meeting), Kriangsak Kittichaisaree of Thailand, whom Professor Sompong Sucharitkul had recommended, and me. Ko explained the urgency of convening this second meeting to its invitees as follows:

After having been at the helm of DILA, including the Yearbook, for the past decade or so, it was time for the 'founding fathers' to prepare an orderly transfer of responsibilities to a younger generation of guardians. Among the parameters that were accepted to be observed in the process were the relocation of the effective centre of decision-making from Europe to somewhere within the region and the principle of collective 
leadership by a body composed of persons from a fair selection of countries of the region. This was in fact to alter the existing situation in which the whole complex of policy- and decision-making had for all practical purposes been centred in the hands of the three founding fathers. The broader basis of the future leadership would admittedly hold positive as well as negative elements, but the former were, after all, considered to be of decisive importance. Since it appeared not feasible to select a group of persons as envisaged from among the existing membership of the Governing Board and the Yearbook Editorial Board, it was decided to compose such a group from among the circle of younger colleagues whose expertise was beyond doubt and who had already shown their dedication to DILA in the past years. ${ }^{31}$

Even though I had done so little for DILA in the preceding three years, I was astonished to find out that I was still somehow considered to be among those who had shown a dedication to the cause of DILA.

The group that met at The Hague was small, just six of us plus the three founders. Ko and Pinto kindly arranged for us to be billeted in a quaint bed and breakfast type accommodation in picturesque Leiden, just ten minutes from the Institute of International Studies (Iss) in The Hague, where we held our meetings from 16 to 17 January 200o. Each morning, the three founders would arrive at our inn and take us in their cars to Iss. Our discussions were serious, but our hosts ensured we all a wonderful time, touring both The Hague and Leiden and enjoying probably the best Indonesian food outside Asia. By this time, the founders of DILA were anxious to get the succession plan underway and for the Core Group to spearhead the leadership transition. Ko recalled:

A group of six dedicated colleagues, coming from Iran to Japan and from China to Singapore, jointly committed themselves to actually take over the duties and responsibilities previously held by the 'founding fathers'. In order to ensure that the selected 'core group' acquired the formal positions held by their three predecessors in all respects, six of them have been elected members of the Governing Board as well as the Editorial Board of the Yearbook (with a seventh to follow soon). One member of the 'core group' has so far been elected co-General Editor of the Yearbook, and it is planned that the existing other General Editors will also be replaced in the near future. ${ }^{32}$

$31 \quad \mathrm{Ko}\left(\mathrm{n}_{7}\right)$.

32 Id. 
By the end of the Hague meeting, the six of us were elected to the Governing Board. It was collectively felt that a seventh Board member from India should be co-opted, and the plan was to approach Professor Bhupinder Singh Chimni at the Jawaharlal Nehru University. ${ }^{33}$ More renewal will take place as the terms of the other existing Governing Board Members expires.

Surya Subedi was also elected to join the founders as co-General Editor of the Yearbook, replacing Joop Syatauw, who stepped down. A plan was also put in place for Ko and Pinto to step down as General Editors by 2002 and for younger General Editors to be appointed. A small Executive Committee, made up of Kriangsak (Chairman), Jamal Seifi (Vice-Chairman), and Nakatani Kazuhiro (Treasurer), was also formally constituted to take over the duties which the former informal Executive Committee (comprising the three founders) performed.

The meeting also decided that for DILA to advance more international law activities in Asia, a separate bank account would be set up in Tokyo. The funds in the Netherlands would be used primarily for expenses connected with the Yearbook, while the account in Japan would be used for DILA's general non-Yearbook activities. Everyone at the meeting was concerned with the circulation and impact of the Yearbook, given its pricing. After some discussion, it was decided that the Core Group would try to find a good publisher in Asia for the Yearbook or licence the Yearbook to a publisher in Asia to produce and distribute a cheaper Asian edition throughout the region.

For my part, I came prepared to make some amends for my lack of action over the last few years. In 1998 I took over as Executive Director of the Society for International Law, Singapore (sILs) from my colleague Robert 'Bob' Beckman. Before arriving at The Hague, I managed to secure concurrence from my sILs colleagues that if funds could be raised, sILS would work with DILA to jointly host a small conference in Singapore on 'Teaching and Researching International Law in Asia'. siLs President Tommy Koh agreed to help raise funds for such a conference if DILA was keen to collaborate. I was thus able to take this offer to the DILA Governing Board at the Hague meeting, and it was received with great enthusiasm after I made my little presentation. This was one of the quickest resolutions to be passed. It was unanimously agreed that I would lead a team to work out the practicalities of this conference. I was also asked to continue working with Surya on the DILA website and design a logo and new letterhead for DILA. This led to the adoption of the image of an 'Asian lamp' as DiLA's logo.

33 Later on, Chimni joined DILA as one of the General Editors of the Yearbook, while his colleague, Bharat Desai joined the Governing Board. 
The question of relocating the seat of DILA to an Asian country was placed on the back burner since it was more symbolic than practical and did not in any way impede DILA from fulfilling its objectives and mission. The meeting ended with everyone thanking the founders for their tireless work for DILA and being such wonderful hosts. A special thanks were given to Joop Syatauw for hosting us at Iss and wishing him well in his retirement. Alas, that was the last I ever saw of Joop. He passed away on 8 February 2015.

\subsection{The 2001 Singapore Conference}

As promised at the 2000 Hague meeting, I immediately mobilised my Singapore colleagues to help organise the first-ever siLs-DiLA Conference, held from 30 to 31 July 2001. As I have given a thorough account of this conference and its accomplishments elsewhere, ${ }^{34}$ I will only recount some critical events and decisions taken at this meeting. This conference was initially scheduled to be held in November or December of 200o, but due to difficulties in scheduling and fund-raising, it was postponed to July 2001. Tommy eventually raised the requisite funds for a small conference of 6o participants from the Lee Foundation and the Tan Chin Tuan Foundation.

Given our limited capacity, I endeavoured to bring in scholars from as many Asian jurisdictions as possible. We managed to invite scholars from 18 jurisdictions, including Singapore: Australia, Bangladesh, Bhutan, China, Hong Kong, India, Indonesia, Iran, Japan, Malaysia, Nepal, Pakistan, the Philippines, South Korea, Sri Lanka, Thailand, Vietnam, United States of America, and Singapore. Also present at the conference was DiLA benefactor, Mike Sata, who flew in on his own to join us. Sata took a deep interest in all that we did and was genuinely concerned for the welfare of our organisation. It was most unfortunate that he committed a faux pas during one discussion when he expressed dismay as to why China had not forgiven Japan so many years after the War even though Japan had apologised and had been extending large amounts of aid to Japan. This created a huge uproar, and the Chinese scholars almost staged a walkout. I never imagined that scholars - supposedly independently minded, logical people - would do something like this. It took all the diplomacy of Tommy Koh and my personal relations with the Chinese scholars to prevent the whole thing from escalating out of proportion. I thought these things only happened

34 I have given a detailed write-up on this particular conference and the results of an important survey done pursuant to the conference in Kevin YL Tan, "The SILS-DILA Conference on "Teaching and Researching International Law in Asia": Report and Reflections' (2001) 5 Singapore Journal of International \& Comparative Law 441-484. 
at the United Nations. It was my shocking introduction to the politics that prevailed even in scholarly circles where some scholars acted more like proxies for their states than independent individuals. This outburst was terribly unfortunate, especially since I found Sata to be a genuine and well-intentioned humanitarian.

Insofar as Singapore was concerned, this was the second time we were hosting an international law conference on teaching and research. The first - the Regional Conference on Legal Education - was organised by the Association of Law Teachers and Schools in Southeast Asia back in 1964. Singapore would host the third conference of this sort almost two decades later when the Centre for International Law at NUS organised the 'Teaching and Researching International Law in Asia' Conference in June 2018. In preparation for the discussions that would take place in the 2001 Conference, I devised (with the help of my colleagues Bob Beckman and Thio Li-ann) a survey with 47 questions to determine the state of play in the teaching and research of international law in Asia. This survey was sent to over 50 participants - all of whom would be attending the Singapore conference - and compiled and consolidated. I hoped that answers to this survey would help guide DILA in its focus on future projects and activities. Being focused on research and teaching, we were anxious to discover how these activities were being carried out in the law schools of Asia. Questions included the level at which international law was taught, and whether it was a compulsory or optional subject, whether it was taught in the native tongue on in some other foreign western language. What textbooks were teachers and students using? Did they have reliable and affordable access to online materials? How comprehensive were the international law holdings of university libraries, and whether there was a ready pool of competent scholars and teachers of international law to be tapped on in each jurisdiction?

One upshot of the survey was the proposal for 'someone' to put together an Asian textbook on international law. DiLA was supposed to have done something like this through the Manual of Asian International Law project, but that never came about, especially after Professor Rahmatullah Khan retired from teaching. Another crying need was for good English-language textbooks to be translated into native languages and to publish these translated works in cheap Asian editions, which most students could afford. Many scholars also lamented the poor collection of international law materials in their libraries and asked if DILA could facilitate a book donation project. These were all splendid ideas but were difficult to implement. The sheer logistics involved in getting books to universities in various Asian states was complicated. I tried to pilot a project and got offers from my academic friends at Yale and Stanford to secure donation of older editions of international law textbooks either from publishers or 
their university libraries. Still, the cost of shipping them to Singapore and then distributing them to the different universities in the region proved prohibitive.

During the Singapore meeting, a point that was strongly made was for greater interaction between international law scholars in the region. To this end, it was proposed that a directory of scholars be created and that it might be time to start an Asian Society for international law. It is to this proposal and initiative that I will next turn.

\section{The Asian Society of International Law: An Existential Challenge}

Even though the idea of establishing a pan-Asian society for international law was mooted with great enthusiasm at the 2001 Singapore meeting, the idea was not new. Indeed, as mentioned earlier, DILA's founders had considered this seriously but opted to establish DILA as a foundation because of the foreseeable difficulties such a society would have. However, as the attendees at the Conference were keen to pursue the idea further, DILA members reconsidered the matter afresh. Ko Swan Sik, the prime mover of DILA, wrote an extensive note $^{35}$ to members offering detailed reasons why DILA's founders considered this possibility back in the 1980 os and opted for the foundation model of organisation.

Ko went on to explain why he thought that while it was 'idealistic' to have such a society to bring members of the Asian international law fraternity together, the practicalities of running such an organisation - such as having a permanent secretariat and offering its members attractive benefits like publications and worthwhile activities - remain significant. Funding would always remain a significant and unavoidable issue, and he did not expect that such a society could be funded by member subscriptions alone. If it were realised, the society would still have to be adopted and subsidised by an institution sympathetic to its objects and cause. In closing, Ko suggested that Singapore would be a suitable location for such a society for the following reasons:

With regard to organisational aspects due weight should be accorded to the many existing national sensitivities in Asia. This refers to, inter alia, the 'seat' of the society ... it would appear that Singapore (small, politically and culturally not dominant, yet affluent and well-organised) might

35 Ko Swan Sik, 'Notes on the Idea of an Asian Society of International Law (AS)', 11 Dec 2003 (on file with author). 
qualify positively. If there is such preference in principle, consultation of Ambassador Tommy Koh would be a conditio sine qua non. ${ }^{36}$

In the meantime, other members of the Asian international law fraternity were also trying to work out how to establish such a society. The most arduous push came from former Yearbook editor Onuma Yasuaki of Tokyo University, who, as mentioned above, was instrumental in securing Mike Sata's long-term funding for the Yearbook. According to Onuma, the whole enterprise began with a telephone conversation, late in the summer of 2003, between him and Owada Hisashi, the Japanese diplomat and academic who had, at that time, just been appointed Judge of the International Court of Justice:

He [Owada] told me that he was approached by the leaders of the Foundation for the Development of International Law in Asia (DILA) regarding possible support for the DILA's activities. In response, he suggested that a more ambitious project might better serve the overall purposes of Asian international lawyers. Briefly sharing the conversation he had with them, Judge Owada asked me if I thought an organisation such as an Asian society of international law was feasible. If I thought so, and if I was interested in such a project, he would consider working with me on it. ${ }^{37}$

Onuma admitted to being surprised by Owada's proposal but quickly agreed, especially he had by this time considered DILA to have 'a number of limitations as a major forum for Asian international lawyers'. ${ }^{38}$ At a breakfast meeting Onuma organised on 12 October 2003 for his Japanese colleagues, - Professors Miyoshi Masahiro, Nakatani Kuzihiro and Okuwaki Naoya (who had just been elected President of the Japanese Society for International Law) - it was unanimously agreed that an Asian Society should soon be established. The Japanese scholars seemed concerned that this should proceed quickly since plans were already afoot to establish a European Society of International Law in 2004 in conjunction with the European Journal of International Law. ${ }^{39}$

While Onuma worked closely with his colleagues at the University of Tokyo - Iwasawa Yuji, Nakagawa Junji, Nakatani Kazhhiro and Teraya

\footnotetext{
$36 \quad I d$.

37 Onuma Yasuaki, 'The Asian Society of International Law: Its Birth and Significance' (2011) 1 Asian Journal of International Law 71-82, 73 [hereinafter 'Onuma'].

38 Id. at 74.

39 Ko Swan Sik, 'Record of Discussion with Judge Hisashi Owada' 11 Dec 2003 (on file with author).
} 
Koji - Owada approached Tommy in Singapore for support. Tommy then wrote to a number of us in Singapore for our views on the establishment of the society. In his mail to me, he also asked me if it was true that we were facing major financial difficulties with the Asian Yearbook of International Law. There was a suggestion that if an Asian society was indeed formed, they were keen to take over the editing and publication of the Yearbook from DILA. I wrote back to Tommy, reiterating the same practical difficulties I had raised many times before and that while the Yearbook was able to subsist on the yearly subvention from Mike Sata and from our royalties, we were far from insolvent. I ended my response by saying that unless he could persuade a university or some other research institution to provide the putative society with a home base and subsidise the running of its secretariat, the whole enterprise would fail. Tommy forwarded my email to Owada in its entirety.

Shortly after this exchange, I was informed by Tommy that Owada and a number of his University of Tokyo colleagues would be visiting Singapore to discuss the Asian Society project. The meeting scheduled for 12 to 13 July 2004 and Tommy planned to meet up with them at some point. A plenary meeting was indeed planned for $10.00 \mathrm{AM}$ on the 13th of July at a conference room on the 8th floor of the Institute of Policy Studies (IPS) at NUS, and I was invited as DILA representative. When I entered the conference room, I was ushered to my seat, which was at one end of a very long conference table. As I was early, I had a chance to see who else was attending the meeting by studying place cards around the table. Seated right in the middle section of the table were Tommy and Dean Tan Cheng Han of the NUs Law Faculty on one side, and Owada, Onuma and Iwasawa on the other.

It was a very strange meeting, with most of the conversation being carried out between Tommy and Owada. I suppose I should not have been too surprised, considering how well the two of them know each other. It was like a meeting of the Law of the Sea old boys' network - that group of diplomats who worked together for over a decade leading up to the signing of the UN Convention for the Law of the Sea in 1982. Everyone addressed each other by their first names, and the atmosphere was all very clubby and chummy. Towards the end of the meeting, Tommy canvassed views from those around the table, and I repeated the same reservations that I expressed in my email to Tommy. At that point, Owada picked up the printout of my email. Never looking me in the eye, he addressed me very slowly, formally and deliberately as 'Dr Tan' and then proceeded to dismiss my reservations before letting the printout drop from his fingers to float contemptuously back onto the table. ${ }^{40} \mathrm{He}$ then looked

40 In obvious reference to this episode, Onuma wrote that 'Negative and even pessimistic views were also presented' at the meeting. Id. 
at Tommy and Dean Tan Cheng Han and announced that these little difficulties' can easily be worked out. Only then did I realise what had happened. A deal had obviously been struck the day before for NUS to house the new society and act as its secretariat. As I later discovered, not only did Tommy succeed in convincing Dean Tan to agree to this, at least for an initial period of three years, but he also convinced the Law Faculty to convert its Singapore Yearbook of International Law into the Asian Journal of International Law. It was a fait accompli, and there was nothing else to say. The meeting concluded shortly afterwards, and Tommy, Owada and his delegation left for lunch together.

On 8 December 2004, Owada invited Ko Swan Sik and Chris Pinto - the two remaining active founders of DILA - for lunch at The Hague to discuss developments and canvas views thereon. ${ }^{41}$ Owada asked Ko and Pinto where DILA would stand in relation to the new Society and what would be the preferred path to take if given three options: (a) further independent development of DILA and an Asian Society as two completely separate entities; (b) two closely coordinated and co-operating entities; or (c) the integration of the existing DILA into the projected Asian Society. Ko told Owada that there were adherents for each of the three alternatives within DILA's Governing Board but that he preferred the third option. Pinto, on the other hand, preferred the second option. This was not the first meeting Ko had with Owada. In December 2003, they met along with DILA Chairman Kriangsak Kittichaisaree in The Hague and discussed establishing the Asian Society and where Ko explained to Owada that DILA's financial needs were for its activities rather than the publication of the Yearbook. ${ }^{42}$

Things moved quickly for the promoters of the Asian Society after the Singapore meeting. After all, two of the most important things they needed had been settled - the seat of the Society and its journal. Both of these would be provided by the NUS Faculty of Law. Following a series of five preparatory meetings - in Tokyo (October 2004); Beijing (March 2005); Seoul (December 2005); Bangkok (July 2006); and Tokyo again (October 2006) plans were finalised to launch the Asian Society of International Law at the NUS in Singapore on 7 July 2007. Ko Swan Sik attended the Beijing meeting and informed the promoters that while DILA was perplexed as to why a different society was needed. Onuma recalled:

An important issue discussed in Beijing was the relationship between the proposed society of Asian international lawyers and the DILA. Professor

\footnotetext{
41 Ko Swan Sik to Dila Governing Board Members, 10 Dec 2004 (on file with author).

42 Ko Swan Sik, 'Record of Discussion with Judge Hisashi Owada' 11 Dec 2003 (on file with author).
} 
Ko Swan Sik, a 'founding father' of the DILA, was invited to the meeting. He told us that the DILA did not oppose the founding of a society of international lawyers in Asia. Nonetheless, Professor Ko was sceptical about the project based on his past experience. Diverse views were expressed as to his opinion, but the majority of the participants considered that an Asian society of international lawyers should be established. They believed that the society could, and should, play an essential role which could not be played by existing organisations, including the DILA; that is, to provide a central forum with an organisational structure comprising mainly (but not limited to) Asian international lawyers, serving as the centre of their research, educational, and practical activities, and fostering and encouraging Asian perspectives of international law. ${ }^{43}$

The active promotion of the Asian Society by our Japanese colleagues gave rise to a major misunderstanding within DILA insofar as finance was concerned. As may be recalled, it was decided at the Hague 2000 meeting that DILA would have two bank accounts - one in the Netherlands for Yearbook expenses and another in Tokyo to receive funds for other DILA activities and programmes. Nakatani Kazuhiro established such an account through the University of Tokyo since Mike Sata indicated his desire to make some of his donations through the university. Unknown to most of us (including Nakatani) at the time, Tokyo University rules forbid funds in its account to be used for activities outside of Japan. As a result, there lay in the Japanese account a sum of $¥ 2 m$ which Sata had donated for DILA's use and generally to support the work of his close friend Onuma. After the University of Tokyo deducted its customary ten per cent administrative fee, $¥ 1.8 \mathrm{~m}$ remained.

The misunderstanding arose when these moneys were used to defray the travel costs of promoters of the Asian Society - namely Onuma, Owada, Iwasawa and Miyoshi - to attend meetings in Singapore and Beijing. Kriangsak, who was the DILA Chairman at the time, protested vehemently to Nakatani and asked why DILA funds were used to promote the Asian Society. Nakatani, who was deeply hurt by this protest, explained in great detail how the series of events that led to the funds being situated in the University of Tokyo and how Mike Sata had confirmed that the funds were intended to support Onuma's international law work and not only DILA's activities. ${ }^{44}$ The storm died down quite quickly after that, but the tensions remained for some time afterwards.

43 Onuma (n 35) 76.

44 Nakatani to Kriangsak \& Dila Governing Board, 3 Apr 2005 (on file with author). 
The rejuvenation of DILA in 2000 led to the election of Kriangsak Kittichaisaree of the Thai Ministry of Foreign Affairs as Chairman for a sixyear term. Several new Governing Board members were also inducted - James Li, Jamal Seifi, Nakatani Kazuhiro, and myself. Much of Kriangsak's tenure as Chairman was spent dealing with the Yearbook and with the emergence of forces that led to the establishment of the Asian Society of International Law. My memory of that period is hazy as we seemed to lurch from crisis to crisis. The Yearbook was behind schedule, and enormous efforts were made to catch up with the backlog. On my end, I could not spend much time on DILA matters, especially after the exacting 2001 SILS-DILA Conference and when I left the University to join the private sector.

I kept in touch with my DILA colleagues, but there were no other big conferences or events to organise or attend. All attention was focused on the Yearbook. One significant development on the Yearbook front was the retirement of Ko and Pinto as General Editors and their replacement by BS Chimni and Miyoshi Masahiro. They were joined in 2005 by my NUS colleague Li-ann Thio. I finally got a functioning website going in 2002 and handed over its management to Bharat Desai.

As the term of the 2000-2006 Governing Board drew to a close, Ko Swan Sik became very anxious about the succession plan for the next Board. Of the younger members of DILA who joined the Board in 2000, James Li was spending more of his time with the Asian Society (saying that he was of much 'greater use' to DILA on the outside rather than in), while Nakatani had pretty much withdrawn from active participation after his big spat with Kriangsak. Jamal Seifi was also busy, and being in Iran, was always a little distant from the locus of action. Ko called me up and asked me to take over as the next DILA Chairman. I was most reluctant to do so since I am not a real international law scholar and did not, till 2006, actually teach international law as a subject. Save for a few human rights pieces, I had published very little in the field of international law. More importantly, I was not significantly plugged into the international law 'circuit' and knew very few international law scholars save for those who participated in DILA activities. I raised these concerns to Ko, who seemed to consider them of little significance. Indeed, Ko and the other Governing Board members had been busy assembling a list of candidates to be appointed to the new Governing Board, most of whom were unknown to me. But Ko was extraordinarily persuasive and reassuring, and I agreed.

With the formation of the Asian Society of International Law, our main differentiating feature was our Yearbook, which was desperately lagging behind 
its publication schedule. I thus saw it my primary responsibility to work on getting the Yearbook back on track. I was also getting the feeling that Brill, our Yearbook publisher, was neglecting us and that we were being charged for simple things like layout, which was ridiculous. I convinced the Governing Board that it was time for us to find a new publisher. Having published several books with Routledge, I approached their commissioning editor to ask if they would consider taking on the Yearbook. I got a very positive response, and Routledge could price the Yearbook at half the price Brill was charging. We moved over to Routledge in 2007 and for the next three years published with them. The project proved unprofitable for Routledge - who had commissioned the Yearbook as a book series rather than a serial publication - and they terminated the contract with DILA in 2010. After that, I decided to publish the Yearbook online and offer it as an open-access publication.

The question of finance and fund-raising was ever-pressing. In October 2006, I received a note from Ko Swan Sik informing me that he had spoken to an old friend, Kartini Muljadi, during a recent trip back to Indonesia about helping DILA with a donation. Ibu Kartini was, as I discovered, one of the richest women in Indonesia, having made her fortune through legal practice and her cosmetics and pharmaceutical companies. Ko informed me that she offered to help DILA work out a strategy for sustainability and offered to make a $€_{25}$,000 donation to our bank account. ${ }^{45}$ This was fantastic news, and Ko asked if I could follow up by writing to her to inform her of our bank coordinates. This was when my nightmare began. I had no idea where our bank account was nor what the number was. I wrote to Surya Subedi, who kindly continued to act as our treasurer even though he was no longer on the Governing Board, and he gave me the coordinates of our bank account in London. In the meantime, I tried to open a bank account in the name of DILA in Singapore and found this to be impossible. The Singapore banks were not permitted to open accounts for entities not domiciled in Singapore. This meant that if DILA wanted to have an account in a Singapore bank, it had to first register itself as a Singapore entity before opening the account. In any case, this to-ing and fro-ing took some two months, and by the time I contacted Ibu Kartini, she did not respond. Ko suggested that I call her home and speak to her, but she proved elusive as the only person I ever got to speak to was her housekeeper. I then asked Ko if he would intervene on our behalf, and he strangely demurred, saying that 'the time is over'.

One other matter with which I found myself constantly having to cope with was the DILA website. When I became Chairman, Bharat Desai was in charge 
of the website. However, when I tried in 2008 to move the website onto a more economical and flexible platform, I was informed that we no longer owned 'asiainternationallaw.org', our original domain name. This was because Desai had somehow forgotten to renew the subscription on the domain name. An attempt to get it back proved futile, ${ }^{46}$ so I decided to register a new domain name - dilafoundation.org - under my name and paid for through automatic annual deductions on my credit card. That way, there would be no danger of our losing our domain name again. By this time, web-based website design software had gotten to a stage where I felt comfortable enough to take on the design of our website on my own so I overhauled the whole website. This website continued to be in use till a new website was established by DILA-Korea in 2018.

When I took over as Chairman, most of the stalwarts of DILA had retired from the Governing Board. After much discussion with Ko, it was decided that I would be assisted by three Vice-Chairpersons - Bharat Desai (India), Jia Bing Bing (China) and Nishii Masahiro (Japan). Other new members of the Board included Surendra Bhandari (Nepal), Noel Dias (Sri Lanka), Javaid Rehman (Pakistan), Nguyen Hong Thao (Vietnam), Azmi Sharom (Malaysia) and Lee Seokwoo (South Korea). I made every effort to meet up with all the new members personally, but it was difficult since we did not often attend the same conferences. However, one such meeting - which took place in Singapore - was to impact DILA's future significantly. This was my meeting with Lee Seokwoo at the launch of the Asian Society of International Law in 2007.

By the time the Asian Society was launched, I had taken over as DILA Chairman, and I represented DILA at the launch event. As this took place in Singapore, I was able to go through the guest list and discover that two new Governing Board members - Lee Seokwoo and Noel Dias - would be present in Singapore, and I made arrangements to meet up with them and to take them out to dinner. Lee had been recommended to our Governing Board by Judge Park Choon Ho, while Dias came highly recommended by M Sornarajah. We all got along very well, and I found them both very enthusiastic and serious about international law. However, it was with Lee that I hit off. He took his role as Board member very seriously and pressed me for a thorough account of how DILA worked and what it sought to do. Most impressively, he kept asking me what he could do to help. This was the start of a 15-year friendship and collaborative partnership that transformed DILA after I stepped down as Chairman.

46 While writing these reflections, I got curious about this and decided to see what became of the 'asianinternationallaw.org' domain name. It is currently available for purchase for USD 40.00 a year. 
The task of finding a role for DILA beyond the Yearbook remained insurmountable so long as DILA remained the small independent organisation that it was. Without a full-time secretariat and institutional financial subvention, we could do little beyond the Yearbook and the odd informal meeting here and there. This situation changed after Lee Seokwoo joined the Governing Board. Lee, a Professor of International Law at INHA University in Incheon, Korea, was a Law of the Sea specialist and was, at the time, Director of the INHA's International Ocean Law Centre. Ever enthusiastic and anxious to advance DILA's mission, Lee proposed holding a joint conference between DILA and his Centre. He made this suggestion to Miyoshi, who was then one of the Yearbook's General Editors in the summer of 2008 but did not get a response. Suspecting that Miyoshi may not have conveyed the offer to the Governing Board, he renewed his offer to host a small conference for up to 15 participants in Seoul on the theme of 'The Law of the Sea, Dispute Settlement, and Colonialism in International Law'. ${ }^{47}$ This was held at Yonsei Law School on 23 April 2010. This small conference marked the beginning of a new era for DiLA. Hereafter, there would be an annual DILA Conference with selected papers being published in the Yearbook. This was made possible by Lee's entrepreneurial leadership; he was incredibly resourceful in raising funds to sustain this annual series of conferences. In 2011, we had yet another meeting at Young Nam University in Daegu, Korea, where we met to present papers on the theme 'Asian Engagements with International Law'.

As my term as DILA Chairman neared its six-year mark, I persuaded Seokwoo to take over as Chairman from 2012. He agreed. Not only was he able to raise funds for our activities, but he was also able to bring on board several energetic scholars like Mario Gomez (Sri Lanka), Kitti Jayangakala (Thailand), Sumaiya Khair (Bangladesh) and Lee Hee Eun (South Korea) as members of the Governing Board. Lee Hee Eun was a particularly valuable addition to the team. He was educated in the United States and taught at the Handong International Law School in Pohang. The unique feature of this law school is that it teaches American law in the English language to prepare students wanting to take an American state bar examination. As an American-styled law school, most Handong students had a native command of the English

47 Most of the papers presented at this conference were published in Paik Jin-Hyun, Lee Seokwoo and Kevin YL Tan (eds), Asian Approaches to International Law: and the Legacy of Colonialism: The Law of the Sea, Territorial Disputes and International Dispute Settlement (London: Routledge 2012) which was primarily edited by me. 
language and were keen on working on law reviews and other legal publications. Hee Eun was able to tap into this by offering student editorial positions and course credits for those willing to help with cite-checking and proofreading the Yearbook. This arrangement was formalised in an MOU, which I signed on behalf of DILA, with Dean Eric Enlow of Handong International Law School on 17 October 2017.

Under Lee's Chairmanship, several significant developments took place. One was the establishment of DILA-Korea, the Korean administrative support arm for DILA and its Yearbook. As I pointed out earlier, municipal banking laws and other government regulations make it very difficult for foreign entities to establish bank accounts and conduct financial transactions without a corresponding local entity domiciled in the host country. At the same time, funders and donors may also be restricted in making donations to locallyregistered entities and not foreign organisations. The second was the annual DILA conference series about which I have already spoken. These conferences have been held in several countries but have primarily been in Korea (where Lee is most successful in raising funds) or in Indonesia, where we can capitalise on the incredible connections and networks of Hikmahanto Juwana (who succeeded Lee as DILA Chairman in 2018) to obtain venue and local hospitality sponsorship. In addition to the academic dimension of each conference, a DILA Academy has also been created where conference participants offer a short one-day course on selected topics in international law to students and staff of the host university. These academies have gone down exceptionally well in Indonesia. Third, the Yearbook, published online during my tenure as Chairman, returned to its old home at Brill in 2016.

In 2018, Hikmanhanto Juwana, one of Indonesia's best-known international law professors, succeeded Lee as Chairman of DILA. Little changed in terms of organisation, with DILA-Korea still providing stellar administrative and organisational support. Under Hikmah's leadership, DILA celebrated its 3oth anniversary, with a conference in Jakarta with the theme of "The Grand Anatomy of State Practice in International Law in Asia in the Last 30 Years: Past, Present and Future'. This milestone event was held at the great hall of the Pancasila Building at Indonesia's Ministry of Foreign Affairs.

\section{Some Reflections}

DiLA has had an event-filled three decades. Conceived at a time when the world seemed so much larger and where connections were less easy to make, and platforms for collaboration were far fewer. Its main achievement has been 
the Asian Yearbook of International Law, which lent voice to Asian scholars of international law and offered the only collection of state practice of the Asian states. This latter contribution continues to be the Yearbook's main strength, and its editors have been relentless in making sure it continues to be produced to the highest standards. Indeed, this prompted Lee Seokwoo and Lee Hee Eun to initiate the massive Encyclopaedia of Public International Law in Asia (State Practice) project with Brill, which will culminate in three volumes covering the state practice of the Asian states. ${ }^{48}$ This is another project which is managed under the auspices of DILA-Korea and taps on the expertise of the various DILA Governing Board and Yearbook Editorial Board members.

Had it not been for the vision and tenacity of Ko Swan Sik, DILA would never have existed. It is remarkable how three Asian scholars, all settled in the Netherlands, should come together to establish a foundation like DILA and to initiate the publication of a serious Yearbook on international law, all without institutional support. A big tribute must be paid to this remarkable team of founders, especially as both Ko and Pinto celebrate their goth birthdays in 2021 , as this goes to press.

Unfortunately, none of the chairmen who came after Ko succeeded in realising the founders' vision and mission for DILA, but that is not for want of trying. Kriangsak was a quiet, reflective leader, always preferring to hear everyone else's views before proffering his own, and his patience almost always outlasted ours. His term was probably the most challenging, especially with all the noise surrounding the establishment of the Asian Society of International Law. I saw myself primarily as a taskmaster brought in to get a job done - mainly to get the Yearbook back on track and perhaps organise the repeat of my 2001 conference. I was fortunate in having Lee Seokwoo on my team. His entrepreneurial energy and resourcefulness pushed DILA to new heights, and we continue to enjoy the fruits of his vast labours. Hikmah is the ultimate deal maker and mobiliser, able to move mountains by typing messages on his handphone.

It has taken the combined abilities of all of our colleagues and us to keep DILA going these twenty-odd years. Will DILA survive another 30 years? Yes, provided it can continue to adapt to changing circumstances, innovate and reinvent itself with each passing epoch. Being small and nimble is probably a good thing in such circumstances. In meeting that challenge, it might be helpful to remember what EF Schumacher has shown, that in many situations, taking small steps in the right direction may be better than taking big ones in the wrong direction. Bigger is not always better; small is beautiful. Happy 3oth Birthday, DILA!

48 The three-volume set is published by Brill and will be available during 2021. 
DILA's office bearers 1989-2019

\begin{tabular}{lll}
\hline Advisory Board Members & From & To \\
\hline Florentino P FELICIANO & 1991 & 2000 \\
Kamal HOSSAIN & 1991 & 2000 \\
N Jasentuliyana & 1996 & 2000 \\
Tommy TB KOH & 1991 & 2000 \\
Mochtar Kusuma-Atmadja & 1991 & 2000 \\
Lee Han Key & 1991 & 1995 \\
Roy S Lee & 1996 & 2000 \\
GKA Lagergren & 1991 & 1995 \\
Frank X Njenga & 1991 & 2000 \\
Park Choon Ho & 1996 & 2000 \\
P Chandrasekhara Rao & 1991 & 2000 \\
S Jamal Seifi & 2018 & Present \\
Visu Sinnadurai & 1991 & 1995 \\
Takabayashi Hideo & 1991 & 2000 \\
Kevin YL Tan & 2018 & Present \\
Wang Tieya & 1991 & 2000 \\
Lal Chand Vohrah & 1996 & 2000 \\
& & \\
\hline
\end{tabular}

\begin{tabular}{lll}
\hline DILA Chairman & From & To \\
\hline Ko Swan Sik & 1989 & 2000 \\
Kriangsak Kittichaisaree & 2000 & 2006 \\
Kevin Y.L. Tan & 2006 & 2012 \\
Lee Seokwoo & 2012 & 2018 \\
Hikmahanto Juwana & 2018 & Present \\
\hline
\end{tabular}

\begin{tabular}{lll} 
Governing Board Members & From & To \\
\hline Arie Afriansyah & 2018 & Present \\
Azmi Sharom & 2006 & 2018 \\
Jay Batongbacal & 2018 & Present \\
Surendra Bhandari & 2006 & 2018
\end{tabular}


DILA's office bearers 1989-2019 (cont.)

\begin{tabular}{|c|c|c|}
\hline Governing Board Members & From & To \\
\hline Bharat Desai & 2002 & 2012 \\
\hline Noel Dias & 2006 & 2012 \\
\hline Tran Viet Dung & 2018 & Present \\
\hline Florentino P Feliciano & 1991 & 2006 \\
\hline Mario Gomez & 2012 & 2018 \\
\hline Jamshed A Hamid & 1991 & 2006 \\
\hline VG Hegde & 2014 & 2018 \\
\hline Kitti Jayangakala & 2012 & Present \\
\hline Jia Bing Bing & 2006 & 2016 \\
\hline Hikmahanto Juwana & 2006 & Present \\
\hline Sumaiya Khair & 2012 & Present \\
\hline Kriangsak Kittichairsaree & 1997 & 2006 \\
\hline Tommy TB Koh & 1997 & 2006 \\
\hline Rahmatullah Khan & 1991 & 2006 \\
\hline Ko Swan Sik & 1991 & 2006 \\
\hline Lee Hee Eun & 2012 & Present \\
\hline Lee Seokwoo & 2006 & Present \\
\hline James Li Zhaojie & 2000 & 2006 \\
\hline Lim Chin Leng & 2006 & 2012 \\
\hline Ronald St J Macdonald & 1991 & 2000 \\
\hline Nakatani Kazuhiro & 2000 & 2006 \\
\hline Nishii Masahiro & 2006 & 2018 \\
\hline Nguyen Hong Thao & 2006 & 2012 \\
\hline Park Choon Ho & 1997 & 2006 \\
\hline MCW Pinto & 1991 & 2006 \\
\hline Javaid Rehman & 2006 & 2018 \\
\hline SJ Seifi & 2000 & 2018 \\
\hline Maria Lourdes Sereno & 2006 & 2014 \\
\hline Kozai Shigeru & 1997 & 2006 \\
\hline Yamamoto Soji & 1991 & 2000 \\
\hline Surya Subedi & 1997 & 2006 \\
\hline Sompong Sucharitkul & 1991 & 2006 \\
\hline JJG Syatauw & 1991 & 2000 \\
\hline Kevin YL Tan & 2000 & 2018 \\
\hline Li-ann Thio & 2014 & 2018 \\
\hline
\end{tabular}


DILA's office bearers 1989-2019 (cont.)

Governing Board Members

Kanami Ishibashi

Matthias Vanhullebusch

Dustin Kuan-Hsiung Wang

Guifang Julia Xue
From

To

$\begin{array}{ll}2018 & \text { Present } \\ 2018 & \text { Present } \\ 2018 & \text { Present } \\ 2018 & \text { Present }\end{array}$

